\title{
Characterization of the cervical mucus plug in mares
}

\author{
S C Loux, K E Scoggin, M H T Troedsson, E L Squires and B A Ball \\ Department of Veterinary Science, University of Kentucky, Lexington, Kentucky, USA \\ Correspondence should be addressed to B A Ball; Email: b.a.ball@uky.edu
}

\begin{abstract}
The cervical mucus plug (CMP) is believed to play an integral role in the maintenance of pregnancy in the mare, primarily by inhibiting microbial entry. Unfortunately, very little is known about its composition or origin. To determine the proteomic composition of the CMP, we collected CMPs from mares $(n=4)$ at 9 months of gestation, and proteins were subsequently analyzed by nano-LC-MS/MS. Results were searched against EquCab2.0, and proteomic pathways were predicted by Ingenuity Pathway Analysis. Histologic sections of the CMP were stained with H\&E and PAS. To identify the origin of highly abundant proteins in the CMP, we performed qPCR on endometrial and cervical mucosal mRNA from mares in estrus, diestrus as well as mares at 4 and $10 \mathrm{~m}$ gestation on transcripts for lactotransferrin, uterine serpin 14, uteroglobin, uteroferrin, deleted in malignant brain tumors 1 and mucins $4,5 b$ and 6. Overall, we demonstrated that the CMP is composed of a complex milieu of proteins during late gestation, many of which play an important role in immune function. Proteins traditionally considered to be endometrial proteins were found to be produced by the cervical mucosa suggesting that the primary source of the CMP is the cervical mucosa itself. In summary, composition of the equine CMP is specifically regulated not only during pregnancy but also throughout the estrous cycle. The structural and compositional changes serve to provide both a structural barrier as well as a physiological barrier during pregnancy to prevent infection of the fetus and fetal membranes.

Reproduction (2017) 153 197-210
\end{abstract}

\section{Introduction}

The mucus formed in the equine cervix during pregnancy (cervical mucus plug - CMP) is believed to play a critical role as a barrier to microbial entry into the pregnant uterus. The cervix of the mare lacks anatomical features such as interlocking cervical rings noted in other large domestic animals (el-Banna \& Hafez 1972, Senger 1999). The CMP may provide an additional physical and physiological barrier protecting the uterus from infiltration of bacteria during pregnancy (Lee et al. 2011).

In women, the CMP has been shown to be important in both the adaptive and innate immune systems. Levels of IgG and IgA are increased significantly in the CMP during pregnancy in women (Hein et al. 2005), and the CMP exhibits an intrinsic antimicrobial activity as well. The CMP is able to inhibit a wide range of both gram-negative and gram-positive bacteria in vitro, including Streptococcus spp., Escherichia coli and Pseudomonas spp. (Hein et al. 2002). A number of other immunologically important proteins such as matrix metalloproteases, azurocidin, cathelicidin antimicrobial peptide and neutrophil defensin have been identified in the CMP of women (Parks et al. 2004, Becher et al. 2010, Lee et al. 2011), although overall knowledge of the proteomic composition of the CMP in species other than humans is sparse.
Three studies have been performed looking at cervical mucus using mass spectrometry in women. The first looked at the overall protein content (AnderschBjorkman et al. 2007, Panicker et al. 2009), as well as O-glycosylation of mucins throughout the menstrual cycle (Andersch-Bjorkman et al. 2007), whereas the other looked specifically at the protein composition of the cervical mucus plug expelled during parturition (Lee et al. 2011). Additionally, an extensive study evaluating the proteome of the cervical mucus, uterine fluid and oviductal fluid in estrus and diestrus ewes was recently published (Soleilhavoup et al. 2016).

Mucins are a primary component of cervical mucus, with relative concentrations of specific mucins varying between pregnant and non-pregnant individuals. In the human, a number of gel-forming and transmembrane mucins are present, including MUC1, MUC4, MUC5B, MUC5AC, MUC6 and MUC16 (Gipson et al. 1999, Andersch-Bjorkman et al. 2007). The physical changes in cervical mucus around ovulation are well documented, with early works showing variation in mucin concentrations between the follicular and luteal phases (Chantler et al. 1989, Gipson et al. 1999, Gipson 2001). Recent evidence suggests that changes in the glycosylation of mucins vary throughout the menstrual cycle as well (Andersch-Bjorkman et al. 2007). 
The origin of the proteins within the CMP is unclear. They may be produced by the cervical mucosa or it has been suggested that the proteins originate from the endometrium, the amnion or amniotic fluids (AnderschBjorkman et al. 2007, Lee et al. 2011). Lee and coworkers (2011) identified a number of proteins of a canonically amniotic origin, whereas Andersch-Bjorkman and coworkers (2007) identified both endometrial cells and proteins within the CMP. To the best of our knowledge, no one has examined whether transcripts of these proteins are produced within the cervical mucosa, the endometrium or the placenta during pregnancy.

Uterine infection during pregnancy is devastating in both humans and in horses. Placentitis is the leading cause of late-term abortion in the mare, causing approximately one-third of such losses (Giles et al. 1993). In ascending placentitis, the bacterial infection appears to originate at the cervix and migrates cranially, causing inflammation, tissue necrosis, placental separation and ultimately resulting in fetal demise (LeBlanc 2010). In the human equivalent of placentitis, chorioamnionitis, the CMP is believed to be key in preventing these infections (Chimura et al. 1993). In women at high risk for chorioamnionitis and preterm birth, the cervical mucus exhibits physically different qualities, including spinnbarkeit, the ability to stretch abnormally to $20 \mathrm{~mm}$ and beyond (Critchfield et al. 2013). Additionally, the mucus was significantly more permeable when challenged with fluorescent microbeads. There is some evidence that a predisposition for placentitis can be introduced by fetal factors, as a recent study showed $7 / 8$ cloned equine pregnancies displayed some indication of placentitis, including $5 / 5$ aborted foals (Pozor et al. 2016).

Cervical mucus plays a potentially critical role as a physical and biochemical barrier to prevent opportunistic infections; however, there is little to no information available about its composition or origin during pregnancy in the horse or other large domestic animals. Therefore, we aimed to characterize the late gestation cervical mucus plug histologically and by characterizing the protein composition using liquid chromatography tandem mass spectrometry (LC-MS/ MS). Additionally, we identified a subset of canonically endometrial proteins, which were highly expressed in the cervical mucus plug and examined the expression of their transcripts throughout the estrous cycle and during late gestation. Expression of these transcripts was evaluated in both cervical mucosa and endometrium with quantitative real-time PCR (qRT-PCR).

\section{Materials and methods}

\section{Animals and tissue collection}

Animal use protocols were approved by the Institutional Animal Care and Use Committee of the University of Kentucky
(\#2014-1341，\#2011-0840，\#2010-0767). All chemicals were purchased from Thermo Fisher Scientific unless otherwise stated. All horses (Equus caballus) used in this study were light-breed horse and pony mares ranging from 250 to $550 \mathrm{~kg}$ housed on pasture with free-choice grass hay available at all times.

Cervical mucus was collected from four pregnant mares (Equus caballus) between 260 and 280 days of gestation by manual intracervical manipulation and extraction. These samples were removed from an unripened cervix without disturbing the pregnancy, so only a partial plug was obtained. Samples were primarily derived from the vaginal portion of the cervix; however, it was not possible to determine the exact orientation of the extracted CMP. Mucus was immediately snap-frozen in liquid nitrogen and stored at $-80^{\circ} \mathrm{C}$ until ready to use.

Cervical mucosa and endometrial tissue samples for RNA isolation were obtained postmortem from mares during estrus $(n=8)$, diestrus $(n=8)$, 4-month gestation $(n=6 /$ cervical mucosa; $n=4$ /endometrium) and 10-month gestation $(n=8)$. Thirty clinically healthy horse and pony mares of different light breeds ranging from 3 to 18 years of age were used in this study. Estrus was defined by the presence of a periovulatory follicle $(\geq 35 \mathrm{~mm})$, and endometrial edema was observed upon transrectal ultrasonography, whereas diestrus samples were taken between 10 and 14 days after ovulation. Diestrus status was confirmed by the presence of a corpus luteum and determination of serum progesterone concentrations. Ovulation was confirmed by daily transrectal palpation and ultrasonography.

After collection, uterine and cervical tissues were dissected into mucosa and muscularis. Separate aliquots were preserved in RNAlater, maintained at $4^{\circ} \mathrm{C}$ for $24 \mathrm{~h}$ per manufacturer's instructions and then stored at $-80^{\circ} \mathrm{C}$ until RNA isolation.

\section{Histological evaluation}

Cervical mucus was fixed in formalin for $>24 \mathrm{~h}$ prior to embedding in paraffin. Sections were cut using a rotary microtome and affixed to slides. Histology was evaluated after hematoxylin and eosin staining using an automated Sakura Prisma stainer (Torrance, CA, USA), following manufacturer's instructions. Periodic acid-Schiff (PAS) staining was performed to localize mucins and other heavily glycosylated proteins. This technique used the DAKO PAS automated kit AR172 and the DAKO Artisan machine, as per manufacturer's instructions.

\section{Protein isolation and liquid chromatography tandem mass spectrometry (LC-MS/MS)}

Protein was isolated from cervical mucus by pulverizing samples under liquid nitrogen using a stainless steel mortar and pestle. Powdered mucus was weighed and reconstituted with T-PER protein extraction buffer with $1 \times$ HALT protease inhibitor at a concentration of $1.0 \mathrm{~mL}$ to $0.1 \mathrm{~g}$ of mucus. Samples were incubated on ice for $30 \mathrm{~min}$ to allow for complete resuspension of proteins with regular vortexing. After incubation, samples were centrifuged at $16,000 \mathrm{~g}$ for $15 \mathrm{~min}$ at $4{ }^{\circ} \mathrm{C}$ to remove debris and then frozen at $-20^{\circ} \mathrm{C}$ until processed for mass spectrometry. 
Prior to mass spectrometry, proteins underwent acetone precipitation. Working with $25 \mu \mathrm{L}$ of protein solution, three additions of cold acetone, $50 \mu \mathrm{L}$ each, were made while vortexing the sample. Proteins were allowed to precipitate during an overnight storage at $-20^{\circ} \mathrm{C}$. Precipitate was collected by centrifugation at $12,000 \mathrm{~g}$ for $20 \mathrm{~min}$, the supernatant was removed and the pellet was allowed to air dry for $20 \mathrm{~min}$.

To digest the pellet, $3.3 \mu \mathrm{g}$ of trypsin (Sigma T 6567) was added in $40 \mathrm{mM}$ ammonium bicarbonate, followed by a $4-\mathrm{h}$ incubation at $37^{\circ} \mathrm{C}$ with shaking. The sample was then reduced in $10 \mathrm{mM}$ dithiothreitol for $30 \mathrm{~min}$ at $56^{\circ} \mathrm{C}$. This was followed by alkylation by $50 \mathrm{mM}$ iodoacetamide in the dark at room temperature for $30 \mathrm{~min}$. A second overnight (18h) digestion at $37^{\circ} \mathrm{C}$ occurred with the addition of $4 \mu \mathrm{g}$ of trypsin. Upon completion of digestion, $95 \% \mathrm{HCOOH}(1 \mu \mathrm{L})$ was added and sample volume was reduced by vacuum centrifugation to $20 \mu \mathrm{L}$ for LC-MS/MS.

Peptides were injected for nano-LC-MS/MS analysis. LC-MS/MS analysis was performed using an LTQ-Orbitrap mass spectrometer (Thermo Fisher Scientific) coupled with an Eksigent Nanoflex cHiPLC system (Eksigent, Dublin, CA, USA) through a nano-electrospray ionization source. The peptide samples were separated with a reversed phase $\mathrm{cHiPLC}$ column $(75 \mu \mathrm{m} \times 150 \mathrm{~mm})$ at a flow rate of $300 \mathrm{~nL} / \mathrm{min}$. Mobile phase A was water with $0.1 \%(\mathrm{v} / \mathrm{v})$ formic acid, whereas B was acetonitrile with $0.1 \%(\mathrm{v} / \mathrm{v})$ formic acid. A 50-min gradient condition was applied: initial 3\% mobile phase B was increased linearly to $50 \%$ in $24 \mathrm{~min}$ and further to $85 \%$ and $95 \%$ for 5 min each before it was decreased to $3 \%$ and re-equilibrated. The mass analysis method consisted of one segment with eight scan events. The 1 st scan event was an Orbitrap MS scan (100-1600 m/z) with 60,000 resolution for parent ions followed by data-dependent MS/MS for fragmentation of the 7 most intense ions with collisioninduced dissociation (CID) method.

The LC-MS/MS data were submitted to a local Mascot server for MS/MS protein identification via Proteome Discoverer (version 1.3, Thermo Fisher Scientific) against the Equus caballus genome (EquCab2.0; www.ncbi.nlm.nih. gov/genome). Parameters used in the MS/MS ion search were trypsin digest with maximum of two miscleavages, cysteine carbamidomethylation, methionine oxidation, a maximum of $10 \mathrm{ppm}$ MS error tolerance and a maximum of $0.8 \mathrm{Da} \mathrm{MS} /$ MS error tolerance. A decoy database was built and searched. Filter settings that determine false discovery rates (FDR) were used to distribute the confidence indicators for the peptide matches. Peptide matches that pass the filter associated with the strict FDR (with target setting of 0.01) were assigned as high confidence. For MS/MS ion search, proteins with two or more high confidence peptides were considered unambiguous identifications without manual inspection. Proteins identified with one high confidence peptide were manually inspected and confirmed. The presence or absence of any given protein in any individual horse is noted in Supplementary Fig. 1 (see section on supplementary data given at the end of this article).

Ingenuity Pathway Analysis software (Qiagen) was used to determine which pathways are putatively present within the cervical mucus based on the proteomic analysis from LC-MS/ MS evaluation of the CMP.

\section{$R N A$ extraction and $q P C R$ analysis}

Total cellular RNA was extracted from endometrium and cervical mucosa using TRIzol Reagent according to the manufacturer's recommendation. The RNA was precipitated as previously described (Ball et al. 2013). Quantification of RNA was performed via spectrophotometry (NanoDrop 2000; Thermo Fisher Scientific), and samples with a 260/280 ratio of 1.95 or greater, and a 260/230 ratio of 2.0 or greater were used for analysis. RNA samples $(1 \mu \mathrm{g} /$ reaction) were treated with rDNase I for $30 \mathrm{~min}$ at $37^{\circ} \mathrm{C}$, followed by treatment with DNase Inactivation Reagent (room temperature for $2 \mathrm{~min}$ ), RNA was then reverse transcribed using the TaqMan Reverse Transcription Reagents.

We identified six proteins for further analysis. These proteins were selected for being highly abundant in the CMP and having previously been reported to be expressed by the endometrium. Specifically, we examined uterine serpin 14 (SERPINA14) (Padua \& Hansen 2010), uteroglobin (secretoglobin family $1 \mathrm{~A}$ member 1; SCGB1A1) (Cote et al. 2014), uteroferrin (acid phosphatase 5; ACP5) (Padua et al. 2012) lactotransferrin (LTF) (Kolm et al. 2006) and deleted in malignant brain tumors 1 (DMBT1) (Yuan et al. 2014). We also looked at transcripts from mucin 4 (MUC4), mucin 5B (MUC5B) and mucin 6 (MUC6). Unfortunately, we were unable to design a satisfactorily specific primer for equine mucin 5AC. The mRNA expression of select transcripts was quantified by real-time quantitative PCR (qPCR) in endometrium and cervical mucosa. Primers (Table 1) were designed using Primer-BLAST from the National Center for Biotechnology Information (Ye et al. 2012). Realtime qPCR of duplicate samples was performed using the

Table 1 Sequences of primers used in the quantitative real-time PCR experiments.

\begin{tabular}{llll}
\hline Gene name & Accession number & Forward primer & Reverse primer \\
\hline ACP5 & NM_001246672.1 & GTTCTACACAGCCCGGGAAA & GAATGTCTCCTGGAACCGCT \\
B2M & NM_001082502.3 & GTGTTCCGAAGGTTCAGGTT & ATTTCAATCTCAGGCGGATG \\
DMBT1 & XM_014732986.1 & TTTCCAAGAGACGCCAGCTT & CACCTGGGCATCCTGAATGT \\
EEF1A1 & NM_001081781.1 & CAACATCGTCGTCATTGGGC & CAGCAGCCTCCTTCTCGAAT \\
GUSB & XM_014729943.1 & GGGATTCGCACTGTGGCTGTCA & CCAGTCAAAGCTTCCCTCGGA \\
LTF & NM_001163974.1 & GGCAGCAAAATGCGCCAAATTCCA & TCTGCCTTGTTTGCCGCGATGG \\
MUC4 & XM_014732832.1 & TGAACGCCACCCTCAATCAG & AGCTTGGTCTTCCCGATGTG \\
MUC5B & XM_014729573.1 & ATGACGAGGACGGCAACTAC & TGCACTGGATGCCATTAGGG \\
MUC6 & XM_014729569.1 & TGCCGTACAAGACTCGCAAT & TGTACACCTGGACACAGGC \\
SCGB1A1 & NM_001081858.2 & CACACCTGCCAGTTTCGA & GCTTTCATGTCTGCATCA \\
SERPINA14 & NM_001242444.1 & ACGCAGGACGATTCGACTTT & AGTGCACCAATCTCGTGTCC \\
\hline
\end{tabular}


ViiA-7 Real-Time PCR System (Thermo Fisher Scientific). Reactions contained a mixture of cDNA (5 ng), primers (25 ng each) and a SYBR Green Master Mix. Cycle parameters of polymerase chain reaction were $95^{\circ} \mathrm{C}$ for $10 \mathrm{~min}$, followed by 40 cycles of $95^{\circ} \mathrm{C}$ for $15 \mathrm{~s}$ and $60^{\circ} \mathrm{C}$ for $1 \mathrm{~min}$, and then a dissociation step of $95^{\circ} \mathrm{C}$ for $15 \mathrm{~s}$. Melting curves for each sample were assessed to evaluate the specificity of the reaction. PCR efficiencies were calculated using LinRegPCR (version 2013.0) (Ruijter et al. 2009). All reactions were pipetted using the epMotion Automated Pipetting Systems (Eppendorf; Hauppauge, NY, USA).

The $\Delta C_{\mathrm{T}}$ for each gene of interest was calculated by subtracting the $C_{\mathrm{T}}$ of the housekeeping gene from the $C_{\mathrm{T}}$ of the gene of interest. Using Normfinder software, the most stable normalization value in cervical mucosa was obtained by averaging the housekeeping genes $\beta$-glucuronidase (GUSB) and eukaryotic translation elongation factor 1 alpha 1 (EEF1A1), whereas $\beta$-2-microglobulin (B2M) was the most stable reference transcript for endometrium (Andersen et al. 2004). Gene expression data are presented as relative quantification values. Changes in relative abundance of specific transcripts were examined by calculating the fold change using the $2^{-\Delta \Delta C T}$ method (Livak \& Schmittgen 2001).

\section{Immunohistochemistry}

Protein localization of mucin 4, uteroglobin and lactoferrin was evaluated by immunohistochemistry (IHC). Cervical mucosa and endometrial tissue samples were obtained postmortem from mares during estrus $(n=2)$, diestrus $(n=2)$ and late pregnancy $(n=3)$. Tissues were fixed in $10 \%$ formalin for $24 \mathrm{~h}$, and then stored in $100 \%$ methanol at $4^{\circ} \mathrm{C}$ until they were dehydrated and embedded in paraffin. Slides were sectioned at $5 \mu \mathrm{M}$ and stained with mouse antimucin 4 monoclonal antibody (1:100 dilution, sc-33654, Santa Cruz Biotechnology), goat anti-lactoferrin polyclonal antibody (1:00, sc-14434, Santa Cruz Biotechnology) or rabbit anti-uteroglobin (1:500 dilution, generous gift from Prof. Jörg Klug, University of Giessen) (Ellenberger et al. 2008). Slides were processed with the Leica BOND-MAX system (Leica Microsystems). Briefly, automated dewaxing and rehydration steps were followed by heat-induced $\left(100^{\circ} \mathrm{C}\right.$ for $20 \mathrm{~min}$ ) antigen retrieval using $\mathrm{pH} 8.8$ EDTA-based ready-to-use solution (Leica Biosystems). The slides were subsequently incubated with $3 \%$ hydrogen peroxide $(5 \mathrm{~min})$, optimally diluted primary antibody $(15 \mathrm{~min})$, a postprimary blocking reagent (to prevent nonspecific polymer binding) (8 min), horseradish peroxidase-labeled polymer (8 min) and diaminobenzidine substrate $(10 \mathrm{~min})$. All reagents were components of the Bond Polymer Refine detection system (Leica Biosystems). Primary antibodies were diluted to optimal concentration using Bond Primary Antibody Diluent (Leica Biosystems). Washing steps between each reagent were performed using Bond Wash Solution 10× Concentrate (Leica Biosystems) diluted to a $1 \times$ working solution with distilled water. Negative controls were prepared in the absence of primary antibody (data not shown). Slides were observed at $200 \times$ magnification.

\section{Statistics}

The $\Delta C_{\mathrm{T}}$ values for estrus, diestrus and pregnancy of endometrium and cervical mucosa for SERPINA14, SCGB1A1, ACP5, LTF, DMBT1, MUC4, MUC5b and MUC6 were compared by one-way ANOVA. When there were differences between the three groups, $\Delta C_{T}$ values were compared by Tukey's post hoc analysis. Values for $\Delta \Delta C_{\mathrm{T}}$ were converted to fold change in expression using $2^{-(\Delta \Delta C T)}$. A $P$ value of 0.05 or less was considered statistically significant. Statistical analyses were carried out using JMP 11.0 (SAS Institute, Cary, NC, USA).

Significance levels for pathways identified by Global Canonical Pathways in Ingenuity Pathway Analysis were calculated using the right-tailed Fisher exact test. Significance was set at $P<0.01$.

\section{Results}

\section{Gross and histological evaluation}

Equine cervical mucus is present in variable quantities between 260 and 280 days of gestation. Although the consistency of the CMP varied from mare to mare, overall, it tended to be a very viscoelastic material with a reddish-orange to pink color (Fig. 1).

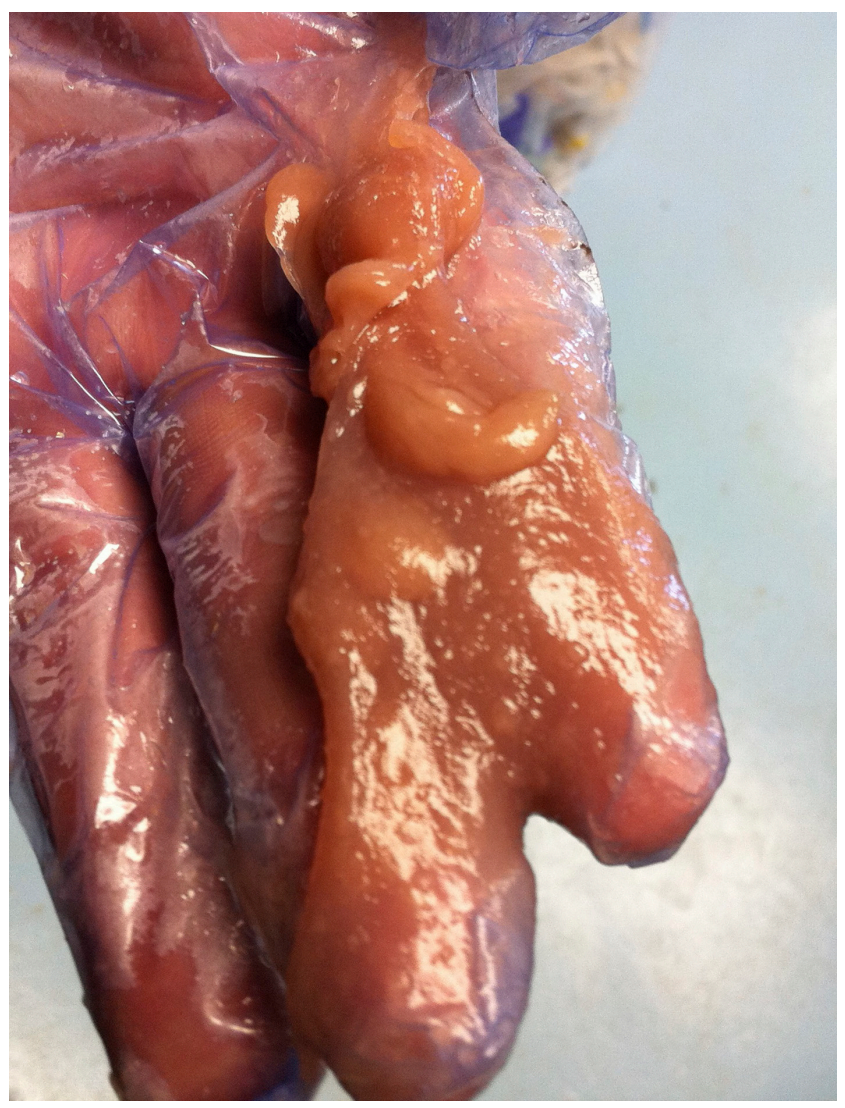

Figure 1 Image of cervical mucus recovered from a mare at 9 months of gestation. Cervical mucus was removed by digital manipulation of cervix, with the quantity of mucus varying by mare. 

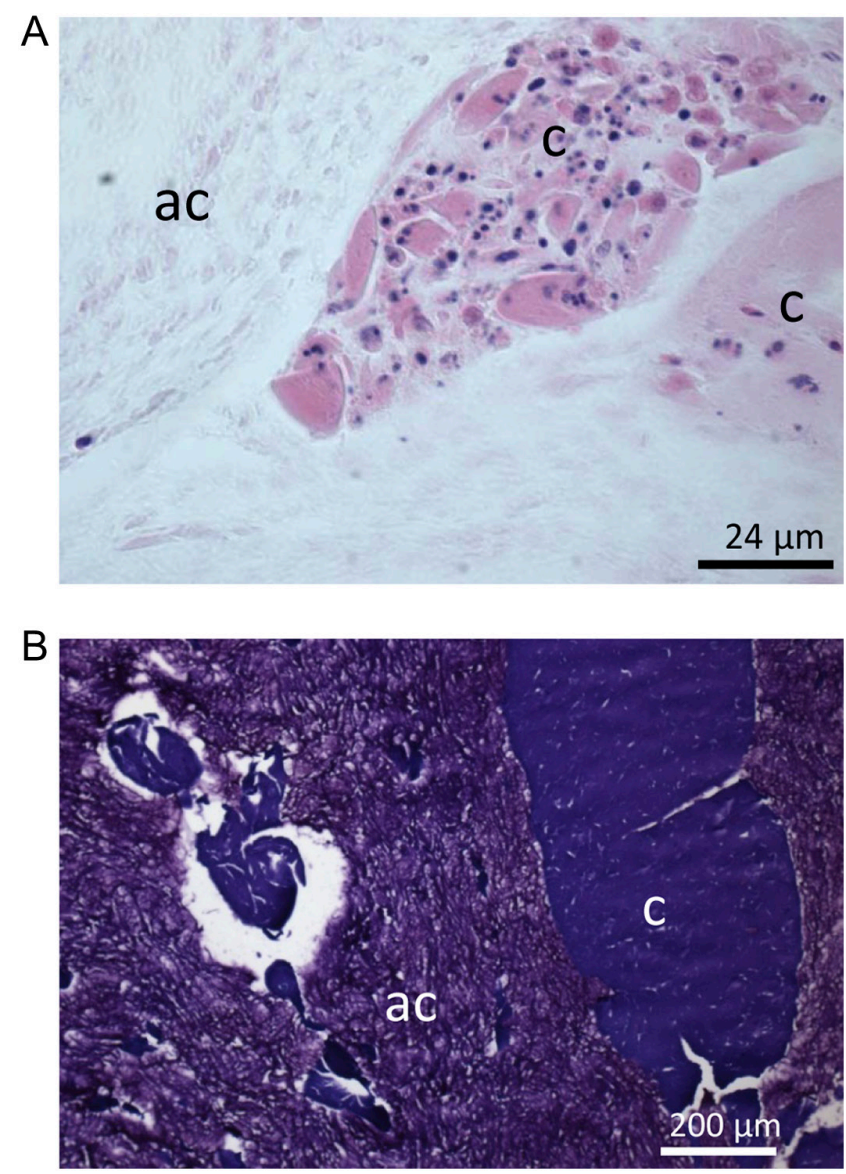

Figure 2 Micrograph of equine cervical mucus recovered at 9 months of gestation. Cervical mucus was stained with either (A) hematoxylin and eosin or (B) periodic acid-Schiff stain. The cellular region is noted with ' $\mathrm{C}$ ', the a-cellular region with 'ac'. Scale is indicated by the bar at the lower right corner of each image.

Histological evaluation revealed two very distinct cellular and a-cellular regions within the cervical mucus plug (Fig. 2A). The cellular region contained numerous cell nuclei that tended to be karyorrhexic or pyknotic. PAS staining for glycosylation reveals positive staining through both the a-cellular and cellular regions (Fig. 2B).

\section{Protein isolation and liquid chromatography tandem mass spectrometry (LC-MS/MS)}

Overall, 218 proteins from the Equus caballus genome (EquCab2.0) were identified in equine cervical mucus during late gestation using LC-MS/MS (Supplementary Table 1). Of these, 63 proteins had one or more isoforms that were indistinguishable, with an average of 2.5 isoforms for every affected protein. Discounting the nondistinguishable isoforms, a total of 179 distinct proteins were identified across all four samples. These proteins were primarily proteins with innate and acquired immune functions. The most abundant protein across all mares was lactotransferrin (LTF), followed closely by immunoglobulins (Ig). Of the immunoglobulins, IgA was the most abundant, followed by IgG and then IgM. SERPINA 14 was the most abundant uterine serpin. Numerous proteins related to the innate immune system were present including complement (C3, C6, Factor $B$ and I), pantheinase, secretoglobin, serotransferrin and chitotriosidase (Supplementary Table 1). There were multiple highly abundant proteins, which have previously been shown to be produced by the endometrium, including SERPINA14, LTF, SCGB1A1, ACP5 and DMBT1. The most abundant mucin in each of the four mares was mucin-5B (MUC5B), followed by mucin-5AC (MUC5AC), mucin-4 (MUC4) and mucin-6 (MUC6) respectively.

\section{Pathway analysis}

We performed protein pathway analysis with Ingenuity Pathway Analysis to better assess putative function of the cervical mucus proteins identified in this study. In total, 38 pathways were denoted as present $(P<0.01$; Table 2). These pathways were largely immunological in basis, with a total of 20/38 pathways with a reported immune function. The pathways with the lowest $P$ values included liver $X$ receptor/retinoic acid receptor (LXR/RXR) activation, clathrin-mediated endocytosis signaling, acute phase response signaling, bile acid receptor/retinoic acid receptor (FXR/RXR) activation, complement system and caveolar-mediated endocytosis signaling. Pathways with shared proteins are indicated in Supplementary Fig. 1.

\section{qPCR analysis}

Real-time quantitative PCR was performed on both cervical mucosa and the corresponding endometrium during diestrus, estrus and late pregnancy. In cervical mucosa, transcripts for SERPINA14, ACP5 and LTF were expressed at significantly higher levels during gestation $(P<0.05)$ than during either estrus or diestrus, although LTF expression was only significantly higher at 10-month gestation, not at 4 months (Fig. 3A, B and D). Expression of SCGB1A1 was significantly higher at $10 \mathrm{~m}$ gestation than diestrus; however, there was no significant difference between estrus samples and pregnant samples (Fig. 3C). Additionally, DMBT1 was significantly higher at $10 \mathrm{~m}$ gestation than either estrus or $4 \mathrm{~m}$ gestation (Fig. 3E). None of these transcripts exhibited differences between estrus and diestrus in the cervical mucosa.

Within the endometrial samples, three transcripts (SERPINA14, ACP5 and LTF) were expressed at the highest level in pregnancy $(P<0.05$; Fig. $4 \mathrm{~A}, \mathrm{~B}$ and $D)$. The expression of ACP5 and LTF was significantly lower at $4 \mathrm{~m}$ than $10 \mathrm{~m}$ gestation, but still increased over non-pregnant samples. SERPINA14 and LTF were differentially expressed between estrus and diestrus as well as pregnant and non-pregnant samples. 
Table 2 Canonical pathways in cervical mucus. Pathways identified as present in cervical mucus proteome using Ingenuity Pathway Analysis $(P<0.001)$.

\begin{tabular}{|c|c|c|}
\hline Pathway name & $-\log (P$-value $)$ & Molecules present \\
\hline LXR/RXR activation* & 9.92 & LYZ, S100A8, TF, C3, CLU, ORM2, APOH, RBP4, PLTP, A1BG, ALB \\
\hline Clathrin-mediated endocytosis signaling* & 9.07 & LYZ, S100A8, TF, CLU, ORM2, ACTC1, ACTA2, ACTA1, RBP4, ACTG2, UBC, ALB \\
\hline Acute phase response signaling* ${ }^{\circ}$ & 8.36 & CFB, HP, TF, C3, CP, ORM2, APOH, C4BPA, RBP4, PLG, ALB \\
\hline FXR/RXR activation* & 7.28 & TF, C3, CLU, ORM2, APOH, RBP4, PLTP, A1BG, ALB \\
\hline Complement system* & 5.64 & CFB, C3, CFI, C4BPA, C6 \\
\hline Caveolar-mediated endocytosis signaling* & 5.44 & АCTC1, В2M, АCTA2, АCTA1, ACTG2, ALB \\
\hline Pyruvate fermentation to lactate* & 5.42 & LDHC, LDHA, LDHB \\
\hline $\begin{array}{l}\text { Production of nitric oxide and reactive } \\
\text { oxygen species in macrophages* }\end{array}$ & 4.98 & LYZ, S100A8, CLU, ORM2, RAP1B, RBP4, RAP1A, ALB \\
\hline Leukocyte extravasation signaling* & 4.68 & EZR, ACTC1, RAP1B, ACTA2, ACTA1, THY1, RAP1A, ACTG2 \\
\hline Atherosclerosis signaling & 4.06 & LYZ, S100A8, CLU, ORM2, RBP4, ALB \\
\hline Mechanisms of viral exit from host cells* & 4.03 & ACTC1, ACTA2, ACTA1, ACTG2 \\
\hline $\begin{array}{l}\text { IL-12 signaling and production in } \\
\text { macrophages* }\end{array}$ & 3.89 & LYZ, S100A8, CLU, ORM2, RBP4, ALB \\
\hline MSP-RON signaling pathway* & 3.83 & АCTC1, АСТА2, АСТA1, АСТG2 \\
\hline Virus entry via endocytic pathways* & 3.76 & ACTC1, B2M, ACTA2, АCTA1, АCTG2 \\
\hline Primary immunodeficiency signaling* & 3.76 & IGLL1/IGLL5, IGHG3, IGHG4 \\
\hline Integrin signaling* & 3.67 & TSPAN1, ACTC1, RAP1B, ACTA2, ACTA1, RAP1A, ACTG2 \\
\hline $\begin{array}{l}\text { Fc } \gamma \text { receptor-mediated phagocytosis in } \\
\text { macrophages and monocytes* }\end{array}$ & 3.67 & EZR, ACTC1, ACTA2, ACTA1, ACTG2 \\
\hline Epithelial adherens junction signaling & 3.67 & ACTC1, RAP1B, ACTA2, ACTA1, RAP1A, ACTG2 \\
\hline RhoGDI signaling & 3.28 & CDH13, EZR, ACTC1, ACTA2, ACTA1, ACTG2 \\
\hline B cell receptor signaling* & 3.26 & CALM1, RAP1B, IGHG3, RAP1A, IGHG4 \\
\hline Calcium signaling & 3.21 & CALM1, ACTC1, RAP1B, ACTA2, ACTA1, RAP1A \\
\hline Remodeling of epithelial adherens junctions & 3.18 & АCTC1, АCTA2, АCTA1, АCTG2 \\
\hline Agrin interactions at neuromuscular junction & 3.15 & ACTC1, ACTA2, ACTA1, АCTG2 \\
\hline RhoA signaling & 3.13 & EZR, ACTC1, ACTA2, ACTA1, ACTG2 \\
\hline Allograft rejection signaling* & 2.83 & B2M, IGHG3, IGHG4, GZMB \\
\hline FAK signaling & 2.78 & АCTC1, АCTA2, АCTA1, АCTG2 \\
\hline $\begin{array}{l}\text { Crosstalk between dendritic cells and } \\
\text { natural killer cells* }\end{array}$ & 2.74 & ACTC1, ACTA2, ACTA1, ACTG2 \\
\hline Regulation of actin-based motility by Rho & 2.71 & АСТC1, АСТА2, АСТА1, АСТG2 \\
\hline Death receptor signaling* & 2.69 & АCTC1, АCTA2, АСТA1, АCTG2 \\
\hline VEGF signaling & 2.69 & АCTC1, АCTA2, АCTA1, АCTG2 \\
\hline Signaling by Rho family GTPases & 2.6 & CDH13, EZR, ACTC1, ACTA2, ACTA1, ACTG2 \\
\hline Autoimmune thyroid disease signaling & 2.59 & IGHG3, IGHG4, GZMB \\
\hline Phospholipase C signaling & 2.58 & CALM1, RAP1B, IGHG3, RAP1A, IGHG4 \\
\hline Paxillin signaling & 2.54 & ACTC1, ACTA2, ACTA1, АCTG2 \\
\hline Corticotropin releasing hormone signaling & 2.39 & CALM1, KRT1, RAP1B, RAP1A \\
\hline NRF2-mediated oxidative stress response & 2.39 & SOD3, ACTC1, ACTA2, ACTA1, ACTG2 \\
\hline Agranulocyte adhesion and diapedesis* & 2.3 & EZR, ACTC1, ACTA2, ACTA1, ACTG2 \\
\hline Actin cytoskeleton signaling & 2.06 & EZR, ACTC1, АCTA2, ACTA1, АCTG2 \\
\hline
\end{tabular}

*Indicates a reported immune function.

A1BG, alpha-1-B glycoprotein; ACTA1, alpha-1 actin, skeletal muscle; ACTA2, alpha-2 actin, skeletal muscle; ACTC1, alpha-1 actin, cardiac muscle; ACTC2, alpha-2 actin, cardiac muscle; ACTG2, gamma-2 actin, smooth muscle; ALB, albumin; APOH, beta-2-glycoprotein; B2M, beta2-microglobulin; C3, complement component 3; C4BPA, complement component 4 binding protein alpha; C6, complement component 6; CALM1, calmodulin 1; CDH13, cadherin 13; CFB, complement factor B; CFI, complement factor I; CLU, clusterin; CP, ceruloplasmin; EZR, ezrin; GZMB, granzyme B; HP, haptoglobin; IGHG3, immunoglobin heavy constant gamma 3; IGHG4, immunoglobulin constant gamma 4; IGLL1/IGLL5; immunoglobulin lambda-like polypeptide 1; LDHA, lactate dehydrogenase A; LDHB, lactate dehydrogenase B; LDHC, lactate dehydrogenase C; LYZ, lysozyme; ORM2, alpha-1-glycoprotein 2-like; PLG, plasminogen; PLTP, phospholipid transfer protein; RAP1A, RAP1A, member of RAS oncogene family; RAP 1B, RAP1b, member of RAS oncogene family; RBP4, retinol-binding protein 4; S100A8, S100 calcium binding protein A8; SOD3, superoxide dismutase 3; TF, transferrin; THY1, Thy-1 cell surface antigen; TSPAN1, tetraspanin 1; UBC, ubiquitin C.

SCGB1A1 showed higher expression in estrus and diestrus when compared to pregnancy (Fig. 4C), whereas DMBT1 exhibited the highest expression in estrus and at $10 \mathrm{~m}$ gestation, with estrus expression 750-fold higher than at $4 \mathrm{~m}$ gestation (Fig. 4E). Overall, changes in expression levels were much more dramatic in endometrial samples than in cervical mucosa, with an average fold change of 16,600 seen in endometrial samples, compared to an average fold change of 1600 in cervical mucosa.
Interestingly, mucin production at $4 \mathrm{~m}$ gestation was significantly lower than any other time point in both endometrial and cervical mucosa samples. Beyond this, there seemed to be no correlation between mucin expression in the endometrium and cervical mucosa. For MUC4, expression levels were highest in endometrial estrus samples, but lowest in the cervical mucosa estrus and $4 \mathrm{~m}$ gestation samples $(P<0.05$; Fig. $5 \mathrm{~A}$ and $\mathrm{B})$. Similarly, expression of MUC4 was the lowest in pregnant endometrial samples, but highest in $10 \mathrm{~m}$ gestation 
A

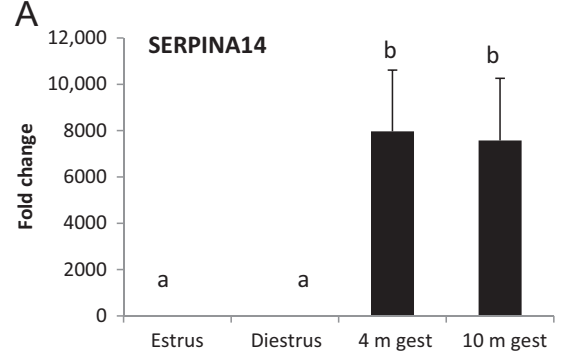

C

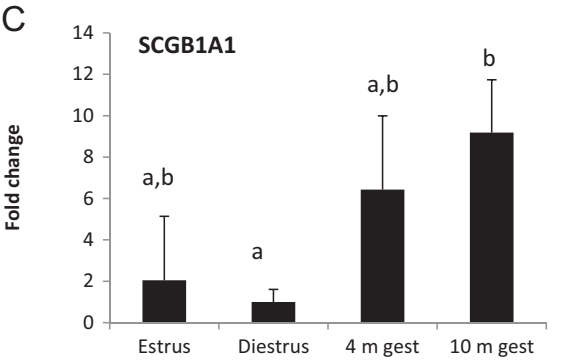

E

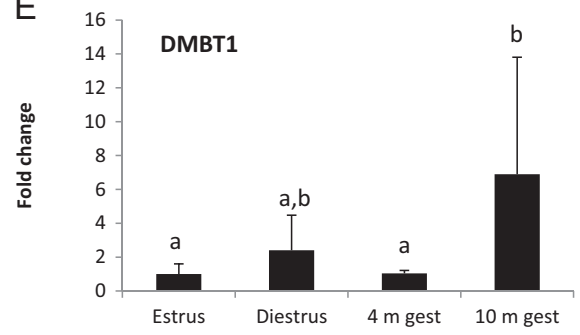

B
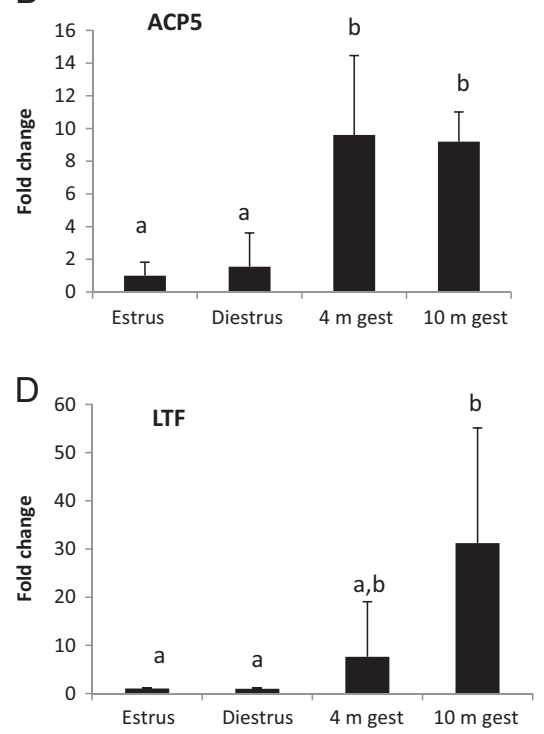

Figure 3 Cervical mucosal transcript analysis during estrus, diestrus and pregnancy. Quantitative PCR was used to determine transcript levels in cervical mucosa during estrus, diestrus, $4 \mathrm{~m}$ and $10 \mathrm{~m}$ gestation. Transcripts evaluated include (A) uterine serpin 14 (SERPINA14); (B) uteroferrin (ACP5); (C) uteroglobin (SCGB1A1);

(D) lactotransferrin (LTF); and (E) deleted in malignant brain tumors 1 (DMBT1). Fold change was calculated as $2^{-\Delta \Delta C T}$. Significance was set as $P<0.05$. Transcripts with significant differences are denoted by varying superscripts. Error bars represent the 95\% confidence interval. cervical mucosa. Expression of MUC5B significantly varied through estrus, diestrus and pregnancy in both the endometrium and cervical mucosa, with the highest expression at $10 \mathrm{~m}$ gestation in both endometrial and cervical mucosa samples. However, during estrus, MUC5B was increased within the endometrium but decreased within the cervical mucosa (Fig. 5C and D). Within the endometrium, MUC6 changed significantly between both stages of pregnancy, estrus and diestrus, with the greatest expression seen during estrus and the least expression during $4 \mathrm{~m}$ gestation $(P<0.05$; Fig. $5 \mathrm{E})$. The only significant difference in MUC6 expression in the cervical mucosa was seen between the $4 \mathrm{~m}$ gestation and $10 \mathrm{~m}$ gestation samples (Fig. 5F).

\section{Immunohistochemistry}

Within the uterus, lactoferrin was detected at the highest level in the 10-month gestation samples and was localized to the endometrial glandular cells, as well as the lumen of the endometrial glands. Both SCGBA1A1 and MUC4 were similarly localized within the glandular cells and glands, and all three proteins were present to some degree within the glandular epithelium in nonpregnant mares (Fig. 6). Within the cervix, all three proteins were specifically localized to the glandular epithelium (Fig. 7).

\section{Discussion}

This study reports, for the first time, the proteomic composition of the equine cervical mucus plug during late gestation. Given the protein composition, equine cervical mucus appears to play a major role in the maintenance of pregnancy and prevention of disease during late gestation, and it is composed of proteins derived from both the innate and acquired immune system. Histologically, the cervical mucus plug is composed of two distinct regions; a cellular region and an a-cellular region, as is seen in other species (Hansen et al. 2014). In the cellular region, the high concentration of pyknotic nuclei is suggestive of polymorphonuclear cells such as neutrophils, basophils and eosinophils. In pregnant women, the cellular portion of the CMP is associated with the vaginal portion of the CMP, whereas the a-cellular portion is directed toward the uterus (Hein et al. 2005). Unfortunately, the method of collection in this study precludes orientation. Both regions stain positively with PAS, indicating that there is a high level of polysaccharides throughout (Arike \& Hansson 2016).

The proteins present within the cervical mucus plug could be loosely categorized into two categories; proteins with immune functions or pregnancy-associated proteins, with several proteins, including lactotransferrin, 
A

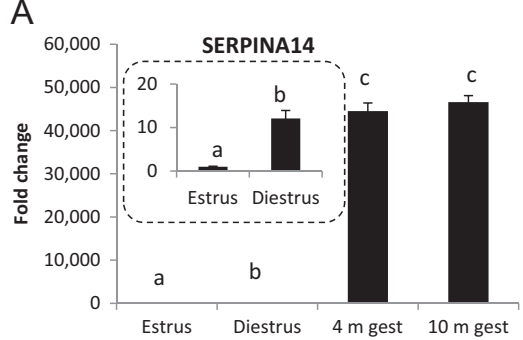

C

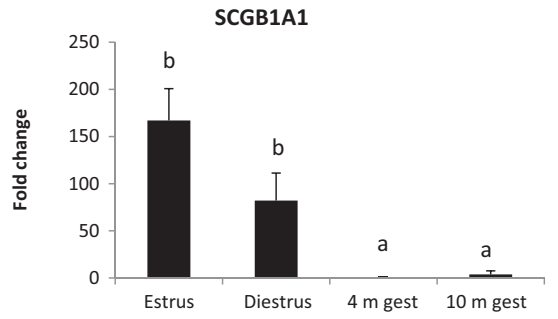

E

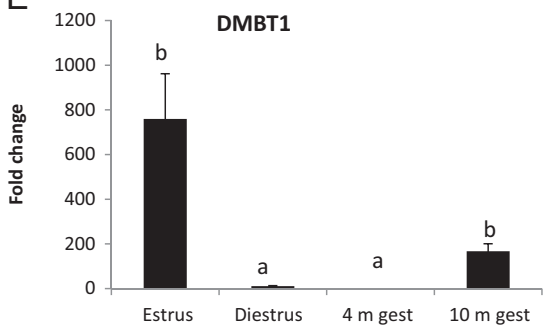

B
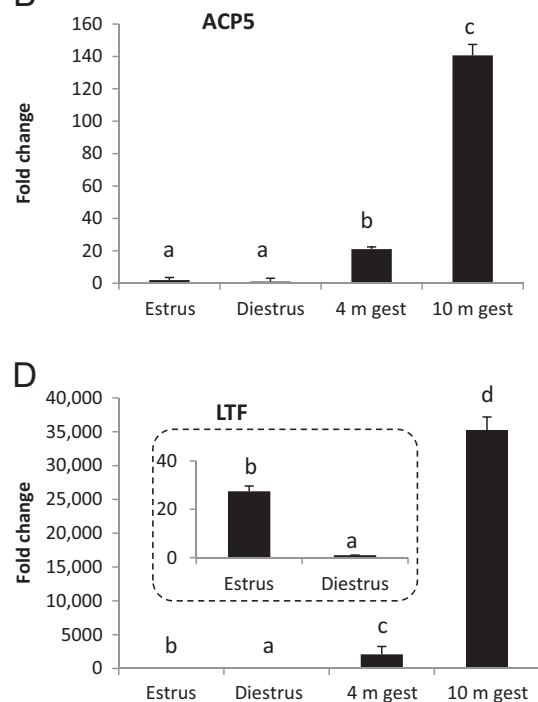

Figure 4 Endometrial transcript analysis during estrus, diestrus and pregnancy. Quantitative PCR was used to determine transcript levels in endometrium during estrus, diestrus, 4 and $10 \mathrm{~m}$ gestion. Transcripts evaluated include (A) uterine serpin 14 (SERPINA14); (B) uteroferrin (ACP5); (C) uteroglobin (SCGB1A1); (D) lactotransferrin (LTF) and (E) deleted in malignant brain tumors 1 (DMBT1). Inset graphs reduce the $y$-axis to allow visualization of all significant values, if required. Fold change was calculated as $2^{-\Delta \Delta C T}$. Significance was set as $P<0.05$. Transcripts with significant differences are denoted by varying superscripts. having a well-documented role in both (reviewed in Teng 2002). Of the top ten pathways identified by Ingenuity Pathway Analysis, nine pathways have a known role in supporting immune function. Clathrinmediated endocytosis signaling, caveolar-mediated endocytosis signaling, the acute phase response system, the complement system, production of nitric oxide and reactive oxygen species in macrophages and leukocyte extravasation signaling all aid white blood cells (WBCs) in identifying and destroying foreign bodies. White blood cells produce energy by the conversion of pyruvate to lactate (Paul et al. 1987), and LXR/RXR and FXR/RXR have been shown to be present in peripheral mononuclear cells and help inhibit apoptosis induced by bacterial stressors, thereby fortifying innate immunity (Valledor et al. 2004, Schote et al. 2007). Although the 10th pathway, atherosclerosis signaling, does not appear to play a role in the immune system, each of the proteins identified in this pathway were also present in at least one of the other top ten pathways, demonstrating that atherosclerosis signaling is not likely present, as well as highlighting the importance of viewing pathway analysis results cautiously.

Overall, the protein composition of the human CMP and the equine CMP appeared to differ significantly. Only $21.1 \%$ of the equine CMP proteins were also found within the human CMP as reported by Lee and coworkers (Lee et al. 2011), whereas the $38.6 \%$ of the proteins from the equine CMP were also found in cervical mucus from the non-pregnant ewe (Soleilhavoup et al. 2016). A subset of proteins reported in all three species include actin, alpha-1B-glycoprotein, alpha2-macroglobulin, annexin 1 and 2, ceruloplasmin, clusterin, complement proteins C6 and B, IgGFCbinding protein, IgG, lysozyme $\mathrm{C}$, plasminogen, protein S100 A8, retinol-binding protein 4 and serotransferrin. Many of the most abundant proteins in the equine CMP were not identified in the human CMP; for example, LTF was absent, although it has been reported previously in the cyclic woman (Hein et al. 2005, Shaw et al. 2007, Lee et al. 2011). Some of the proteins had only minor changes between species, for example, serpin B11 was present in the horse, whereas serpin B5 and B10 were present in the ewe (Soleilhavoup et al. 2016) and serpin B3 was present in the human (Lee et al. 2011).

We found IgA to be the most abundant immunoglobulin within the CMP, followed by $\operatorname{lgG}$, and then $\lg M$. This is in contrast with the findings in the human, which showed $\lg G$ to be the most abundant immunoglobulin in the CMP throughout pregnancy (Kutteh \& Franklin 2001, Hein et al. 2005). IgG is typically present in high concentrations in circulation; it is possible that the CMP in humans is composed of a higher proportion of serum proteins due to the human's hemochorial placentation. Conversely, IgA is known to be most abundant in mucosal surfaces. Interestingly, 
A

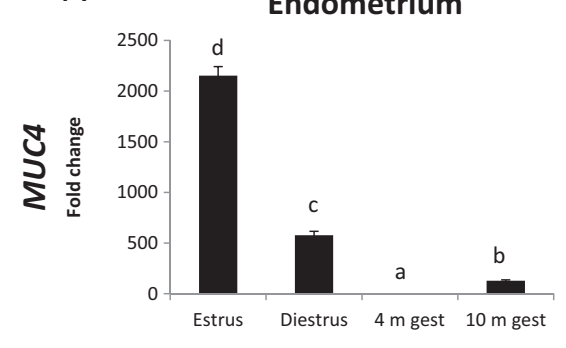

C

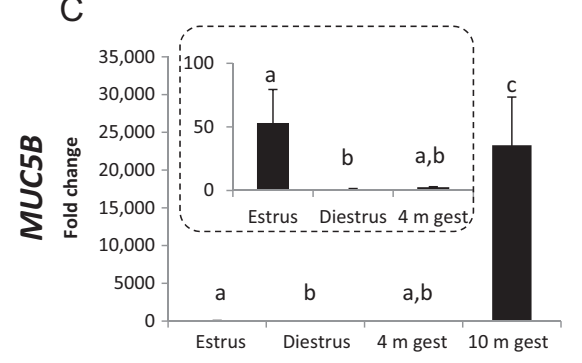

E

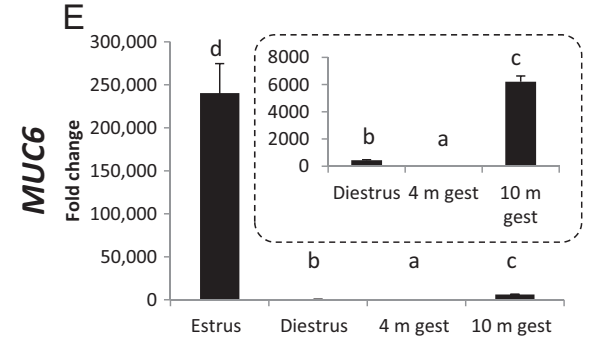

B

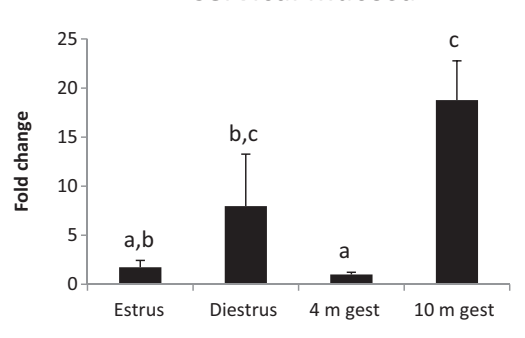

D

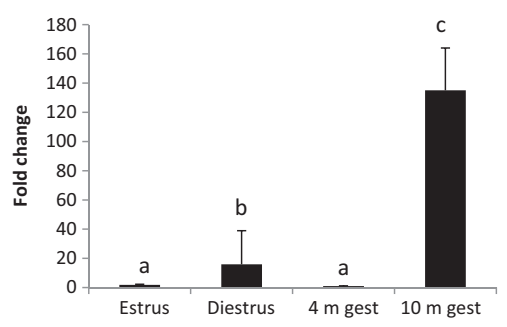

F

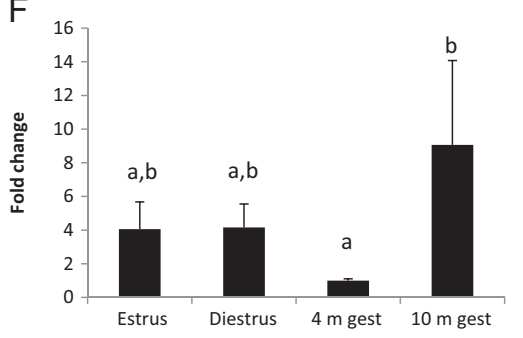

Figure 5 Mucin transcript analysis during estrus, diestrus and pregnancy. Quantitative PCR was used to quantitate mucin transcript levels in (A, C, E) endometrium and (B, D, F) cervical mucosa during estrus, diestrus and $4 \mathrm{~m}$ and $10 \mathrm{~m}$ gestation. Mucins evaluated include (A, B) mucin 4 (MUC4); (C, D) mucin 5B (MUC5B); and (E, F) mucin 6 (MUC6). Fold change was calculated as $2^{-\Delta \Delta C T}$. Inset graphs reduce $y$-axis to allow visualization of all significant values, if required. Significance was set as $P<0.05$. Transcripts with significant differences are denoted by varying superscripts.
IgG passes through the placenta to the fetus in the human (Nagendran et al. 2015), but not in the horse (Jeffcott 1974); this combined with the presence of amniotic proteins in the human cervical mucus plug (Lee et al. 2011) suggests that this may be a source of $\lg G$ in the human CMP. Alternatively, the differential expression of these immunoglobulins may be related to the differing profiles of pregnancy hormones, as immunoglobulin levels are known to be steroid hormone dependent (Kutteh \& Franklin 2001, Lu et al. 2003).

To elucidate the origin of the CMP, we examined six proteins highly expressed in the CMP which have previously been shown to be produced by the endometrium. Transcripts for each of these proteins were found within the cervical mucosa as well as the endometrium and were consistently expressed at the highest level at 10-month gestation in the cervical mucosa. Although transcripts for each of these proteins were found within the endometrium, expression during pregnancy was not consistently higher than non-pregnant endometrium. In fact, expression of SCGB1A1 was lowest within the pregnant endometrium. Furthermore, only four proteins present in the allantoic fluid in the horse were found in the CMP, including serum albumin, serotransferrin, alpha-2-macroglobulin and alpha1B-glycoprotein (our unpublished data). It appears unlikely that allantoic fluid is contributing significantly to the composition of the CMP, particularly as the most abundant protein in allantoic fluid, fibronectin, was not identified in the CMP. Although we cannot rule out the contributions of proteins derived from endometrium, chorioallantois or allantoic fluid, it appears that the cervical mucosa itself is primarily responsible for the formation of the CMP.

Interestingly, several proteins showed drastically different patterns of regulation between the cervical mucosa and endometrium, suggesting these proteins have varying roles based on location and that regulation for these proteins occurs locally. Uteroglobin (SCGB1A1) was upregulated 9-fold in cervical mucosa during pregnancy, but downregulated 160-fold in the pregnant endometrium. Rabbit endometrium exhibits a similar decrease in SCGB1A1, with levels dropping as early as $72 \mathrm{~h}$ after ovulation (Saeed et al. 2015). This decrease appears to be important for successful implantation (Vicente et al. 2013). In humans, endometrial SCGB1A1 is present throughout the menstrual cycle and peaks during the early luteal phase (Muller-Schottle et al. 1999); however, it does not appear to be present in cervical mucus, either during the peri-ovulatory period (Daniel et al. 1987) or during pregnancy (Lee et al. 2011). To the best of our knowledge, SCGB1A1 has not previously been identified in cervical mucosa in any species. 


\section{Endometrium}

\section{Estrus}
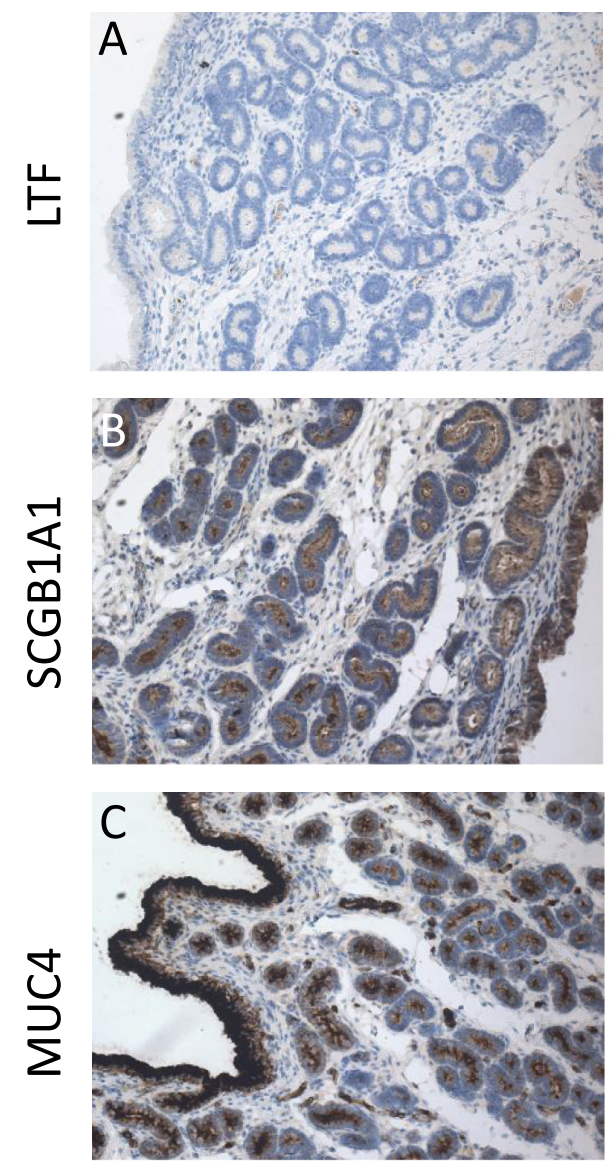

Diestrus
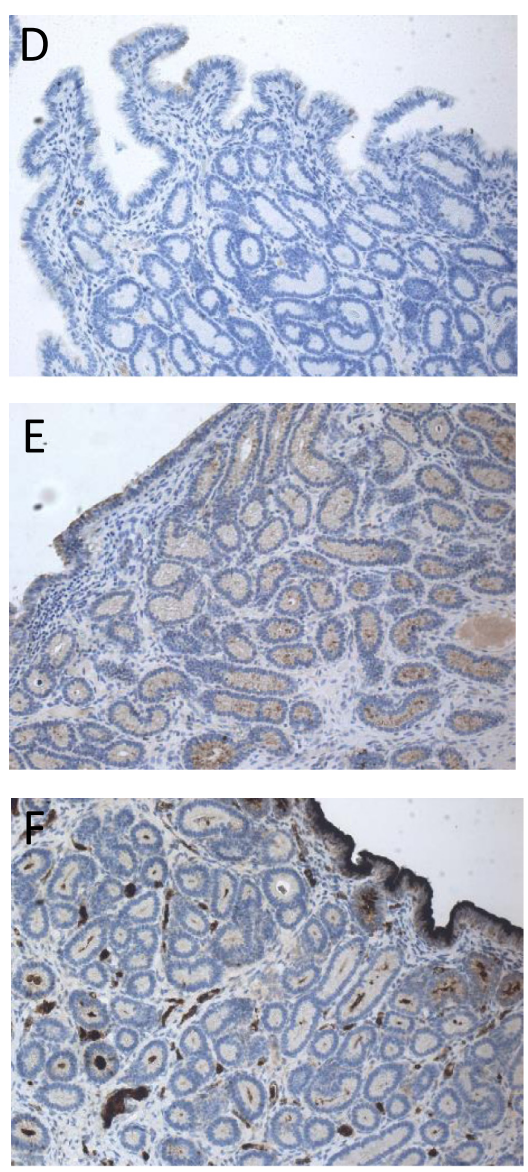

10 m gestation
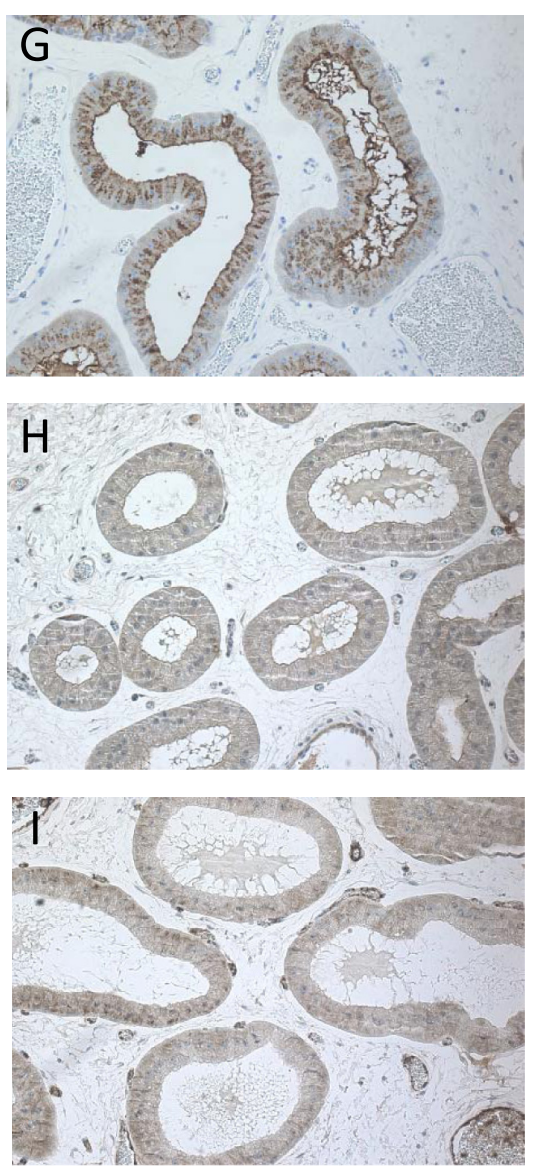

$120 \mu \mathrm{m}$

Figure 6 Immunolocalization of LTF, SCGB1A1 and MUC4 in cervical mucosa. Immunohistochemical localization of LTF, SCG and MUC4 in estrus (A, B, C), diestrus (D, E, F) and late pregnant (G, H, I) cervical mucosa. Magnification of 200x.

DMBT1 exhibited the highest expression during estrus in the endometrium, but expression in the cervical mucosa was lowest during the same period, consistent with findings in the ewe (Soleilhavoup et al. 2016). The high expression of DMBT1 in the estrous endometrium is perhaps not surprising, as it appears to play a role in fertilization in both the pig and the horse (Ambruosi et al. 2013). The upregulation of DMBT1 by the cervical mucosa during diestrus and late pregnancy may be explained by its role in host defense. Belonging to a family of scavenger receptor cysteine-rich genes (Mollenhauer et al. 1997), it is upregulated in response to inflammatory stimuli in lung tissue (Mollenhauer et al. 2002). Additionally, DMBT1 has been shown to modulate bacterial recognition and inhibit invasion of a wide variety of bacteria (Bikker et al. 2002, Rosenstiel et al. 2007).
Lactotransferrin, an estrogen-responsive glycoprotein, was shown to be preferentially expressed during estrus in the non-pregnant endometrium (Fig. 4D) where it has been proposed to inhibit bacterial growth by sequestering free iron (Metz-Boutigue et al. 1984, Newbold et al. 1992, Baker et al. 1998, Kolm et al. 2006). The increased expression during estrus holds true in the mouse, rat, bitch, woman and rhesus monkey (Newbold et al. 1992, Teng et al. 2002a,b, Kida et al. 2006, Kolm et al. 2006). In sheep, there appears to be no increase in LTF within uterine fluids during estrus, and LTF actually decreases in ovine cervical mucus at this time (Soleilhavoup et al. 2016). There is a significant body of evidence that LTF protects against uterine and placental infections and may prevent preterm labor (Mania-Pramanik et al. 1999, Otsuki et al. 1999, Hasegawa et al. 2005, Sawada et al. 2006, Giunta et al. 2012). 


\section{Cervical mucosa}
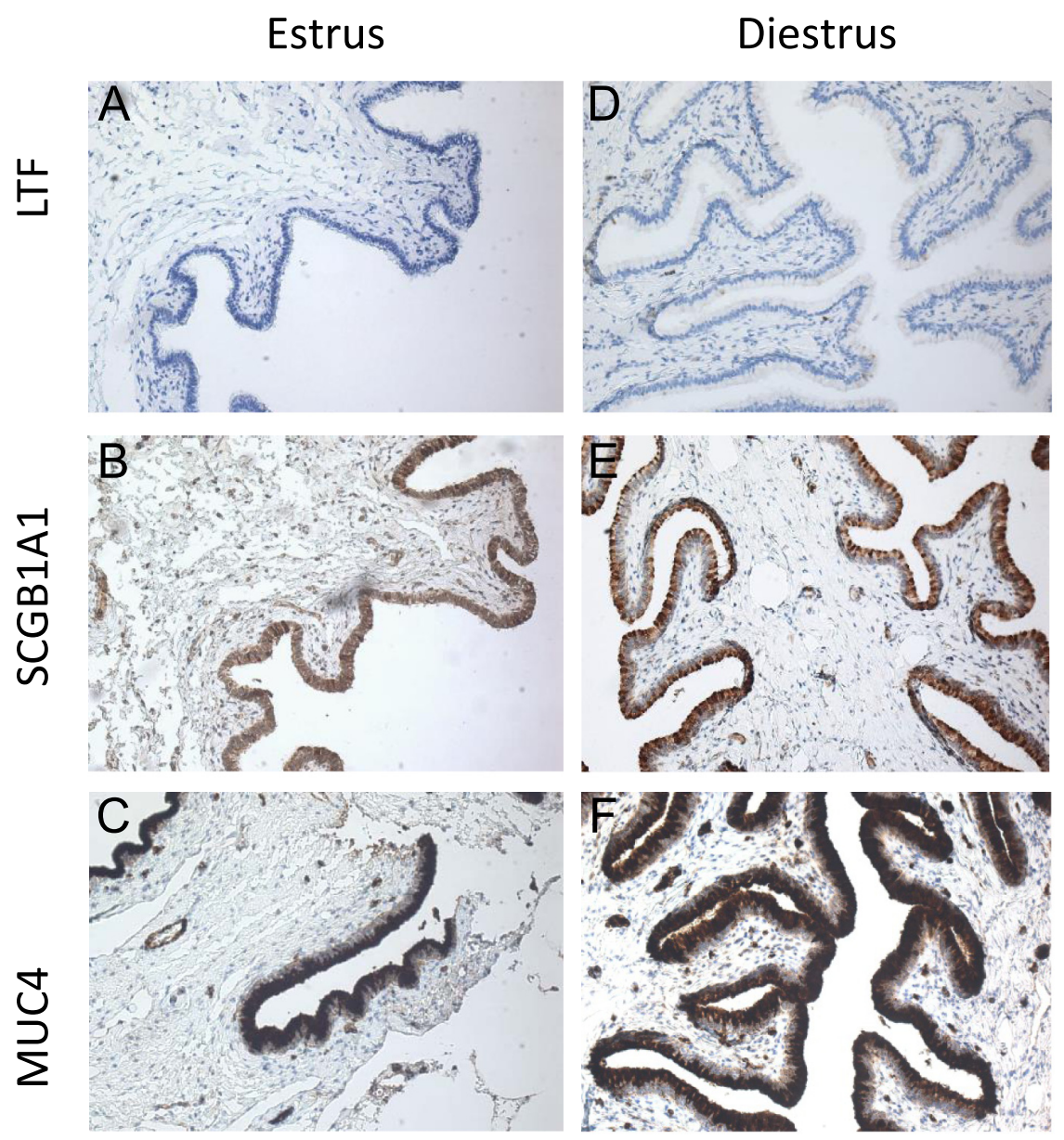

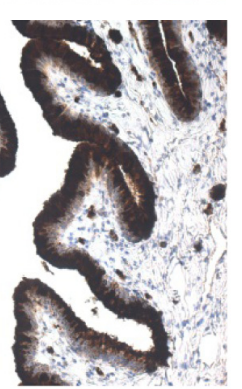

10 m gestation
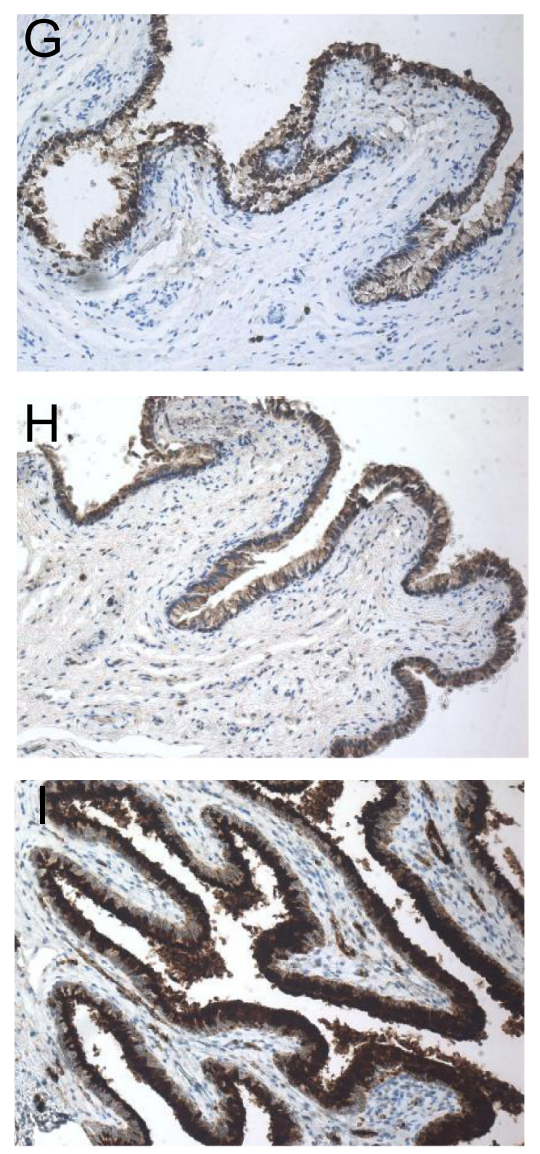

$120 \mu \mathrm{m}$

Figure 7 Immunolocalization of LTF, SCGB1A1 and MUC4 in endometrium. Immunohistochemical localization of LTF, SCG and MUC4 in estrus (A, B, C), diestrus (D, E, F) and late pregnant $(G, H, I)$ endometrial samples. Magnification of 200x.

SERPINA14 and ACP5 were expressed at relatively low levels during estrus and diestrus, but concentrations increased dramatically during pregnancy in both the endometrium and the cervical mucosa (Figs 3 and 4). Both genes are known to be progesterone responsive, accounting for their increased expression during pregnancy (Joshi et al. 1980, Roberts \& Bazer 1988, Padua \& Hansen 2010, Padua et al. 2012). Estrous changes in SERPINA14 were not noted in the ewe, and ACP5 was not identified in either cervical mucus or uterine fluid (Soleilhavoup et al. 2016).

SERPINA14 is a highly expressed immunosuppressive agent and is able to inhibit lymphocyte proliferation by preventing the upregulation of IL2 (Peltier et al. 2000). It has also been shown to form complexes with both IgA and IgM as well, potentially tempering their action against the fetus (Hansen \& Newton 1988). ACP5 plays a well-established role in iron metabolism and is involved in transporting iron to the fetus (Roberts \& Bazer 1988, Young et al. 1989). It is also intricately involved in the immune system and serves as a marker for macrophage activation (Janckila \& Yam 2009).

Mucins also appear to be independently regulated between the cervical mucosa and endometrium, with both MUC4 and MUC6 exhibiting significantly different expression patterns between these tissues (Fig. 5). Within the endometrium, mucins are believed to play a role in modulating signal transduction processes, as well as facilitating cell attachment and implantation (Constantinou et al. 2015). In the cervix itself, mucins have a number of very different roles, including retention of positively charged molecules, inhibiting the diffusion of bacteria and inhibiting viral replication (Hollingsworth \& Swanson 2004, Mall 2008). Given this information, perhaps it should not 
be surprising to see differential regulation between tissues within the reproductive tract.

The CMP provides protection to the fetus on multiple levels. It provides not only structural barrier but also numerous antimicrobial components to prevent placental infection and preterm birth. Changes in its composition can be detrimental to pregnancy outcomes (Critchfield et al. 2013). The structural framework is primarily provided by mucins, which also provide a steric inhibition of bacterial invasion (Becher et al. 2009) as well as inhibiting viral replication (Habte et al. 2008). The CMP is rich in bactericidal proteins including LTF and DMBT1. These proteins are produced by the cervical mucosa itself, where it appears that the majority of the CMPs are manufactured. Contrary to previous beliefs, the CMP does not appear to be primarily composed of extraneous endometrial and fetal proteins, although we cannot rule out their presence. Additionally, many of the proteins we selected for additional study appear to be differentially regulated between the cervical mucosa and the endometrium, suggesting that they are under tightly regulated local control. Overall, the CMP is a very deliberate antimicrobial structure, which provides a formidable barrier against bacterial invasion of the uterus. Expanding our knowledge of equine cervical mucus will provide important information about its role in the maintenance of pregnancy, as well as in the prevention of infectious disease such as placentitis and chorioamnionitis.

\section{Supplementary data}

This is linked to the online version of the paper at http://dx.doi. org/10.1530/REP-16-0396.

\section{Declaration of interest}

The authors declare that there is no conflict of interest which could be perceived as prejudicing the impartiality of the research reported.

\section{Funding}

This research was supported by the Albert G Clay Endowment and the Paul Mellon Postdoctoral Fellowship at the University of Kentucky.

\section{Acknowledgements}

Mass spectrometric analysis was performed at the University of Kentucky, Proteomics Core Facility by Dr Jing Chen and Dr Carol Beach. This core facility is supported in part by funds from the Office of the Vice President for Research.

\section{References}

Ambruosi B, Accogli G, Douet C, Canepa S, Pascal G, Monget P, Moros Nicolas C, Holmskov U, Mollenhauer J et al. 2013 Deleted in malignant brain tumor 1 is secreted in the oviduct and involved in the mechanism of fertilization in equine and porcine species. Reproduction 146 119-133. (doi:10.1530/REP-13-0007)

Andersch-Bjorkman Y, Thomsson KA, Holmen Larsson JM, Ekerhovd E \& Hansson GC 2007 Large scale identification of proteins, mucins, and their O-glycosylation in the endocervical mucus during the menstrual cycle. Molecular and Cellular Proteomics 6 708-716. (doi:10.1074/mcp. M600439-MCP200)

Andersen CL, Jensen JL \& Orntoft TF 2004 Normalization of real-time quantitative reverse transcription-PCR data: a model-based variance estimation approach to identify genes suited for normalization, applied to bladder and colon cancer data sets. Cancer Research 64 5245-5250. (doi:10.1158/0008-5472.CAN-04-0496)

Arike L \& Hansson GC 2016 The densely O-glycosylated MUC2 mucin protects the intestine and provides food for the commensal bacteria. Journal of Molecular Biology 428 3221-3229. (doi:10.1016/j. jmb.2016.02.010)

Baker EN, Anderson BF, Baker HM, MacGillivray RT, Moore SA, Peterson NA, Shewry SC \& Tweedie JW 1998 Three-dimensional structure of lactoferrin. Implications for function, including comparisons with transferrin. Advances in Experimental Medicine and Biology 443 1-14. (doi:10.1038/nmeth0910-687)

Ball BA, Scoggin KE, Troedsson MH \& Squires EL 2013 Characterization of prostaglandin E2 receptors (EP2, EP4) in the horse oviduct. Animal Reproduction Science 142 35-41. (doi:10.1016/j. anireprosci.2013.07.009)

Becher N, Adams Waldorf K, Hein M \& Uldbjerg N 2009 The cervical mucus plug: structured review of the literature. Acta Obstetricia et Gynecologica Scandinavica 88 502-513. (doi:10.1080/00016340902852898)

Becher N, Hein M, Danielsen CC \& Uldbjerg N 2010 Matrix metalloproteinases in the cervical mucus plug in relation to gestational age, plug compartment, and preterm labor. Reproductive Biology and Endocrinology 8 113. (doi:10.1186/1477-7827-8-113)

Bikker FJ, Ligtenberg AJ, Nazmi K, Veerman EC, van't Hof W, Bolscher JG, Poustka A, Nieuw Amerongen AV \& Mollenhauer J 2002 Identification of the bacteria-binding peptide domain on salivary agglutinin (gp-340/ DMBT1), a member of the scavenger receptor cysteine-rich superfamily. Journal of Biological Chemistry 277 32109-32115. (doi:10.1074/jbc. M203788200)

Chantler E, Sharma R \& Sharman D 1989 Changes in cervical mucus that prevent penetration by spermatozoa. Symposia of the Society for Experimental Biology 43 325-336.

Chimura T, Hirayama T \& Takase M 1993 Lysozyme in cervical mucus of patients with chorioamnionitis. Japanese Journal of Antibiotics $\mathbf{4 6}$ 726-729.

Constantinou PE, Morgado M \& Carson DD 2015 Transmembrane mucin expression and function in embryo implantation and placentation. Advances in Anatomy, Embryology and Cell Biology 216 51-68. (doi:10.1007/978-3-319-15856-3_4)

Cote O, Clark ME, Viel L, Labbe G, Seah SY, Khan MA, Douda DN, Palaniyar N \& Bienzle D 2014 Secretoglobin 1A1 and 1A1A differentially regulate neutrophil reactive oxygen species production, phagocytosis and extracellular trap formation. PLOS ONE 9 e96217. (doi:10.1371/ journal.pone.0096217)

Critchfield AS, Yao G, Jaishankar A, Friedlander RS, Lieleg O, Doyle PS, McKinley G, House M \& Ribbeck K 2013 Cervical mucus properties stratify risk for preterm birth. PLOS ONE 8 e69528. (doi:10.1371/journal. pone.0069528)

Daniel JC Jr, Lonergan PB, Sullivan PK \& Taylor SP 1987 Evaluation of 'Determine; The OvuTest' as a device for identifying optimal time for conception. Fertility and Sterility 47 590-596. (doi:10.1016/S00150282(16)59108-0)

el-Banna AA \& Hafez ES 1972 The uterine cervix in mammals. American Journal of Obstetrics and Gynecology 112 145-164. (doi:10.1016/00029378(72)90544-3)

Ellenberger C, Wilsher S, Allen WR, Hoffmann C, Kolling M, Bazer FW, Klug J, Schoon D \& Schoon HA 2008 Immunolocalisation of the uterine secretory proteins uterocalin, uteroferrin and uteroglobin in the mare's 
uterus and placenta throughout pregnancy. Theriogenology 70 746-757. (doi:10.1016/j.theriogenology.2008.04.050)

Giles RC, Donahue JM, Hong CB, Tuttle PA, Petrites-Murphy MB, Poonacha KB, Roberts AW, Tramontin RR, Smith B \& Swerczek TW 1993 Causes of abortion, stillbirth, and perinatal death in horses: 3,527 cases (1986-1991). Journal of the American Veterinary Medical Association 203 1170-1175.

Gipson IK 2001 Mucins of the human endocervix. Frontiers in Bioscience 6 D1245-D1255. (doi:10.2741/A677)

Gipson IK, Spurr-Michaud S, Moccia R, Zhan Q, Toribara N, Ho SB, Gargiulo AR \& Hill JA 3rd 1999 MUC4 and MUC5B transcripts are the prevalent mucin messenger ribonucleic acids of the human endocervix. Biology of Reproduction 60 58-64. (doi:10.1095/ biolreprod60.1.58)

Giunta G, Giuffrida L, Mangano K, Fagone P \& Cianci A 2012 Influence of lactoferrin in preventing preterm delivery: a pilot study. Molecular Medicine Reports 5 162-166. (doi:10.3892/mmr.2011.584)

Habte HH, de Beer C, Lotz ZE, Tyler MG, Schoeman L, Kahn D \& Mall AS 2008 The inhibition of the Human Immunodeficiency Virus type 1 activity by crude and purified human pregnancy plug mucus and mucins in an inhibition assay. Virology Journal 559. (doi:10.1186/1743-422X-5-59)

Hansen PJ \& Newton GR 1988 Binding of immunoglobulins to the major progesterone-induced proteins secreted by the sheep uterus. Archives of Biochemistry and Biophysics 260 208-217. (doi:10.1016/00039861(88)90442-0)

Hansen LK, Becher N, Bastholm S, Glavind J, Ramsing M, Kim CJ, Romero R, Jensen JS \& Uldbjerg N 2014 The cervical mucus plug inhibits, but does not block, the passage of ascending bacteria from the vagina during pregnancy. Acta Obstetricia et Gynecologica Scandinavica 93 102-108. (doi:10.1111/aogs.12296)

Hasegawa A, Otsuki K, Sasaki Y, Sawada M, Mitsukawa K, Chiba H, Nagatsuka M, Okai T \& Kato A 2005 Preventive effect of recombinant human lactoferrin in a rabbit preterm delivery model. American Journal of Obstetrics and Gynecology 192 1038-1043. (doi:10.1016/j. ajog.2005.01.013)

Hein M, Valore EV, Helmig RB, Uldbjerg N \& Ganz T 2002 Antimicrobial factors in the cervical mucus plug. American Journal of Obstetrics and Gynecology 187 137-144. (doi:10.1067/mob.2002.123034)

Hein M, Petersen AC, Helmig RB, Uldbjerg N \& Reinholdt J 2005 Immunoglobulin levels and phagocytes in the cervical mucus plug at term of pregnancy. Acta Obstetricia et Gynecologica Scandinavica $\mathbf{8 4}$ 734-742. (doi:10.1111/j.0001-6349.2005.00525.x)

Hollingsworth MA \& Swanson BJ 2004 Mucins in cancer: protection and control of the cell surface. Nature Reviews Cancer 4 45-60. (doi:10.1038/nrc1251)

Janckila AJ \& Yam LT 2009 Biology and clinical significance of tartrateresistant acid phosphatases: new perspectives on an old enzyme. Calcified Tissue International 85 465-483. (doi:10.1007/s00223-0099309-8)

Jeffcott LB 1974 Some practical aspects of the transfer of passive immunity to newborn foals. Equine Veterinary Journal 6 109-115. (doi:10.1111/j.2042-3306.1974.tb03942.x)

Joshi SG, Ebert KM \& Smith RA 1980 Properties of the progestagendependent protein of the human endometrium. Journal of Reproduction and Fertility 59 287-296. (doi:10.1530/jrf.0.0590287)

Kida K, Baba E, Torii R, Kawate N, Hatoya S, Wijewardana V, Sugiura K, Sawada T, Tamada H \& Inaba T 2006 Lactoferrin expression in the canine uterus during the estrous cycle and with pyometra. Theriogenology $\mathbf{6 6}$ 1325-1333. (doi:10.1016/j.theriogenology.2006.04.028)

Kolm G, Klein D, Knapp E, Watanabe K \& Walter I 2006 Lactoferrin expression in the horse endometrium: relevance in persisting matinginduced endometritis. Veterinary Immunology and Immunopathology 114 159-167. (doi:10.1016/j.vetimm.2006.08.005)

Kutteh WH \& Franklin RD 2001 Quantification of immunoglobulins and cytokines in human cervical mucus during each trimester of pregnancy. American Journal of Obstetrics and Gynecology 184 865-872; discussion 872-864. (doi:10.1067/mob.2001.113853)

LeBlanc MM 2010 Ascending placentitis in the mare: an update. Reproduction in Domestic Animals 45 (Supplement 2) 28-34. (doi:10.1111/j.1439-0531.2010.01633.x)
Lee DC, Hassan SS, Romero R, Tarca AL, Bhatti G, Gervasi MT, Caruso JA, Stemmer PM, Kim CJ, Hansen LK et al. 2011 Protein profiling underscores immunological functions of uterine cervical mucus plug in human pregnancy. Journal of Proteomics 74 817-828. (doi:10.1016/j. jprot.2011.02.025)

Livak KJ \& Schmittgen TD 2001 Analysis of relative gene expression data using real-time quantitative PCR and the 2(-Delta Delta $\mathrm{C}(\mathrm{T})$ ) method. Methods 25 402-408. (doi:10.1006/meth.2001.1262)

Lu FX, Ma Z, Moser S, Evans TG \& Miller CJ 2003 Effects of ovarian steroids on immunoglobulin-secreting cell function in healthy women. Clinical and Diagnostic Laboratory Immunology 10 944-949. (doi:10.1128/ cdli.10.5.944-949.2003)

Mall AS 2008 Analysis of mucins: role in laboratory diagnosis. Journal of Clinical Pathology 61 1018-1024. (doi:10.1136/jcp.2008.058057)

Mania-Pramanik J, Mali BN, Shah RS \& Donde UM 1999 Lactoferrin in cervical mucus as a biochemical marker for inflammation. Indian Journal of Clinical Biochemistry 14 229-236. (doi:10.1007/BF02867923)

Metz-Boutigue MH, Jolles J, Mazurier J, Schoentgen F, Legrand D, Spik G, Montreuil J \& Jolles P 1984 Human lactotransferrin: amino acid sequence and structural comparisons with other transferrins. European Journal of Biochemistry 145 659-676. (doi:10.1111/j.1432-1033.1984. tb08607.x)

Mollenhauer J, Wiemann S, Scheurlen W, Korn B, Hayashi Y, Wilgenbus KK, von Deimling A \& Poustka A 1997 DMBT1, a new member of the SRCR superfamily, on chromosome 10q25.3-26.1 is deleted in malignant brain tumours. Nature Genetics 17 32-39. (doi:10.1038/ng0997-32)

Mollenhauer J, Helmke B, Muller H, Kollender G, Lyer S, Diedrichs L, Holmskov U, Ligtenberg T, Herbertz S, Krebs I et al. 2002 Sequential changes of the DMBT1 expression and location in normal lung tissue and lung carcinomas. Genes, Chromosomes and Cancer 35 164-169. (doi:10.1002/gcc.10096)

Muller-Schottle F, Classen-Linke I, Alfer J, Krusche C, Beier-Hellwig K, Sterzik K \& Beier HM 1999 Expression of uteroglobin in the human endometrium. Molecular Human Reproduction 5 1155-1161. (doi:10.1093/molehr/5.12.1155)

Nagendran V, Emmanuel N \& Bansal AS 2015 Does the maternal serum IgG level during pregnancy in primary antibody deficiency influence the IgG level in the newborn? Case Reports in Immunology 2015286380. (doi:10.1155/2015/286380)

Newbold RR, Teng CT, Beckman WC Jr, Jefferson WN, Hanson RB, Miller JV \& McLachlan JA 1992 Fluctuations of lactoferrin protein and messenger ribonucleic acid in the reproductive tract of the mouse during the estrous cycle. Biology of Reproduction 47 903-915. (doi:10.1095/ biolreprod47.5.903)

Otsuki K, Yoda A, Saito H, Mitsuhashi Y, Toma Y, Shimizu Y \& Yanaihara T 1999 Amniotic fluid lactoferrin in intrauterine infection. Placenta 20 175-179. (doi:10.1053/plac.1998.0368)

Padua MB \& Hansen PJ 2010 Evolution and function of the uterine serpins (SERPINA14). American Journal of Reproductive Immunology 64 265-274. (doi:10.1111/j.1600-0897.2010.00901.x)

Padua MB, Lynch VJ, Alvarez NV, Garthwaite MA, Golos TG, Bazer FW, Kalkunte S, Sharma S, Wagner GP \& Hansen PJ 2012 ACP5 (Uteroferrin): phylogeny of an ancient and conserved gene expressed in the endometrium of mammals. Biology of Reproduction 86123. (doi:10.1095/biolreprod.111.097964)

Panicker G, Lee DR \& Unger ER 2009 Optimization of SELDI-TOF protein profiling for analysis of cervical mucous. Journal of Proteomics $\mathbf{7 1}$ 637-646. (doi:10.1016/j.jprot.2008.11.004)

Parks WC, Wilson CL \& Lopez-Boado YS 2004 Matrix metalloproteinases as modulators of inflammation and innate immunity. Nature Reviews Immunology 4 617-629. (doi:10.1038/nri1418)

Paul JL, el Abbouyi A, Roch-Arveiller M, Giroud JP, Agneray J, Yonger J \& Raichvarg D 1987 Effects of storage on the pyruvate-lactate system and random migration of human granulocytes. Vox Sanguinis 52 24-26. (doi:10.1111/j.1423-0410.1987.tb02983.x)

Peltier MR, Liu WJ \& Hansen PJ 2000 Regulation of lymphocyte proliferation by uterine serpin: interleukin-2 mRNA production, CD25 expression and responsiveness to interleukin-2. Proceedings of The Society for Experimental Biology and Medicine 223 75-81. (doi:10.1046/j.15251373.2000.22310.x) 
Pozor MA, Sheppard B, Hinrichs K, Kelleman AA, Macpherson ML, Runcan E, Choi YH, Diaw M \& Mathews PM 2016 Placental abnormalities in equine pregnancies generated by SCNT from one donor horse. Theriogenology 86 1573-1582. (doi:10.1016/j. theriogenology.2016.05.017)

Roberts RM \& Bazer FW 1988 The functions of uterine secretions. Journal of Reproduction and Fertility 82 875-892. (doi:10.1530/ jrf.0.0820875)

Rosenstiel P, Sina C, End C, Renner M, Lyer S, Till A, Hellmig S, Nikolaus S, Folsch UR, Helmke B et al. 2007 Regulation of DMBT1 via NOD2 and TLR4 in intestinal epithelial cells modulates bacterial recognition and invasion. Journal of Immunology 178 8203-8211. (doi:10.4049/ jimmunol.178.12.8203)

Ruijter JM, Ramakers C, Hoogaars WM, Karlen Y, Bakker O, van den Hoff MJ \& Moorman AF 2009 Amplification efficiency: linking baseline and bias in the analysis of quantitative PCR data. Nucleic Acids Research 37 e45. (doi:10.1093/nar/gkp045)

Saeed AM, Saenz de Juano Mde L, Marco Jimenez F \& Vicente JS 2015 Oviductal and endometrial mRNA expression of implantation candidate biomarkers during early pregnancy in rabbit. Zygote 23 288-296. (doi:10.1017/S0967199413000555)

Sawada M, Otsuki K, Mitsukawa K, Yakuwa K, Nagatsuka M \& Okai T 2006 Cervical inflammatory cytokines and other markers in the cervical mucus of pregnant women with lower genital tract infection. International Journal of Gynecology and Obstetrics 92 117-121. (doi:10.1016/j.ijgo.2005.10.004)

Schote AB, Turner JD, Schiltz J \& Muller CP 2007 Nuclear receptors in human immune cells: expression and correlations. Molecular Immunology 44 1436-1445. (doi:10.1016/j.molimm.2006.04.021)

Senger PL 1999 Pathways to Pregnancy and Parturition. Pullman, WA, USA: Current Conceptions, Inc.

Shaw JL, Smith CR \& Diamandis EP 2007 Proteomic analysis of human cervico-vaginal fluid. Journal of Proteome Research 6 2859-2865. (doi:10.1021/pr0701658)

Soleilhavoup C, Riou C, Tsikis G, Labas V, Harichaux G, Kohnke P, Reynaud K, de Graaf SP, Gerard N \& Druart X 2016 Proteomes of the female genital tract during the oestrous cycle. Molecular and Cellular Proteomics 15 93-108. (doi:10.1074/mcp. M115.052332)
Teng CT 2002 Lactoferrin gene expression and regulation: an overview. Biochemistry and Cell Biology 80 7-16. (doi:10.1139/o01-215)

Teng CT, Beard C \& Gladwell W 2002a Differential expression and estrogen response of lactoferrin gene in the female reproductive tract of mouse, rat, and hamster. Biology of Reproduction 67 1439-1449. (doi:10.1095/ biolreprod.101.002089)

Teng CT, Gladwell W, Beard C, Walmer D, Teng CS \& Brenner R 2002b Lactoferrin gene expression is estrogen responsive in human and rhesus monkey endometrium. Molecular Human Reproduction 8 58-67. (doi:10.1093/molehr/8.1.58)

Valledor AF, Hsu LC, Ogawa S, Sawka-Verhelle D, Karin M \& Glass CK 2004 Activation of liver $X$ receptors and retinoid $X$ receptors prevents bacterial-induced macrophage apoptosis. PNAS 101 17813-17818. (doi:10.1073/pnas.0407749101)

Vicente JS, Saenz-de-Juano MD, Jimenez-Trigos E, Viudes-deCastro MP, Penaranda DS \& Marco-Jimenez F 2013 Rabbit morula vitrification reduces early foetal growth and increases losses throughout gestation. Cryobiology 67 321-326. (doi:10.1016/j. cryobiol.2013.09.165)

Ye J, Coulouris G, Zaretskaya I, Cutcutache I, Rozen S \& Madden TL 2012 Primer-BLAST: a tool to design target-specific primers for polymerase chain reaction. BMC Bioinformatics 13 134. (doi:10.1186/1471-210513-134)

Young KH, Kraeling RR \& Bazer FW 1989 Effects of prolactin on conceptus survival and uterine secretory activity in pigs. Journal of Reproduction and Fertility 86 713-722. (doi:10.1530/jrf.0.0860713)

Yuan Z, Wang L, Wang Y, Zhang T, Li L, Cragun JM, Chambers SK, Kong B \& Zheng W 2014 Tubal origin of ovarian endometriosis. Modern Pathology 27 1154-1162. (doi:10.1038/modpathol.2013.245)

Received 20 July 2016

First decision 23 August 2016

Revised manuscript received 24 October 2016

Accepted 14 November 2016 